\title{
Kinetics Analysis for Anaerobic Co-digestion of Sewage Sludge and Industrial Wastewater
}

\author{
Jeremiah A. Adedeji and M. Chetty
}

\begin{abstract}
The increasing demand for energy has led to the utilization of fossil fuels more abundantly as a quick resort for generation of energy. The use of these sources of energy however as led to the generation of greenhouse gases which tend to cause climate change, thus affecting the ecosystem at large coupled with the continual depletion of these energy sources. Thus, the search for alternative sources of energy which are renewable and has less or no pollution. One of such alternative sources is industrial wastewater which have shown to have high concentration of nutrients in the form of organic contents which can be converted by micro-organisms into energy, usually known as biogas, comprising majorly of $\mathrm{CH}_{4}, \mathrm{CO}_{2}$ and $\mathrm{H}_{2}$. Another important factor is that industrial wastewaters are a renewable energy source which are continuously generated due to increasing urbanization and population growth. In this study, the characteristics of three agro-industrial based wastewaters used shows their potential for application in anaerobic co-digestion technique. Biochemical methane potential (BMP) test of three industrial wastewater effluents: brewery, dairy and sugar wastewater (BW, DW and $\mathrm{SW}$ ) respectively were investigated as co-substrates for sewage sludge (SS) for biogas production. Assays with inoculum -substrate ratio (ISR) of $1: 1$ at $35^{\circ} \mathrm{C}$ and $2: 1$ at $25^{\circ} \mathrm{C}$ for $\mathrm{SW}$ and $\mathrm{DW}$ respectively had the highest methane production within the first three (3) weeks. The kinetic models that best fit the anaerobic co-digestion with SW was the first order model.
\end{abstract}

Keywords - Anaerobic co-digestion, industrial wastewater, kinetic model, sewage sludge.

\section{INTRODUCTION}

Renewable energy generation from waste via anaerobic digestion (AD) of organic matter is gaining recognition as one of the means of mitigating the greenhouse effect and an alternate route for replacement of the depleting non-renewable energy sources. However, despite progress made via the AD process, certain challenges have limited the full implementation of the process on large scales such as instability and low yield of biogas [1]. To mitigate these challenges, various approaches have been employed which include the use of energy crops and organic wastes with high-fat content, but researches have shown that minimal changes occur due to an imbalance in the nutrient source which in turn, affect the stability of the process. Also, to achieve a balanced source of nutrients, the use of different organic wastes with varying composition have been investigated

Manuscript received October 20,2020. This work was supported in part by the NRF South Africa under the Block Grant

J. A. Adedeji is a research student in the Durban University of Technology, Durban, South Africa.

M. Chetty is a Senior Lecturer in the Durban University of Technology, Durban, South Africa. in recent decades with food and vegetable wastes and agricultural biomass being the topmost feedstock used as co-substrates for other organic waste [2]. This strategy is known as anaerobic co-digestion (AcoD), it helps stabilize the process by providing balanced nutrients, accurate moisture content, improve microbial activity via increased organic loading rate and ultimately improve the yield of biogas [3]. Xie[4], defined AcoD as a means of practically managing two or more organic matters simultaneously while improving biogas yield. Municipal wastewater treatment plants are saddled with the responsibility of treating wastewater from domestic and industrial sources. During the treatment process, generation of large quantities of semi-solid waste known as sewage sludge (SS) frequently occurs, SS, if not properly handled could result in the formation of secondary pollutant [5], [6]. Among the various treatment process for managing the $\mathrm{SS}$ produced is $\mathrm{AD}$ which aids in the reduction of organic pollutants while generating biogas in situ, such as any mono-digested substrate SS have also encountered instability in its digestion process. Therefore, the use of SS with food wastes or agricultural energy crops has seen a tremendous increase over the decade [7].

In like manner, the enormous amount of wastewater generated daily from industrial activities and specifically from agricultural processing industries is startling. The wastewater from these industries has been reported to contain high organic pollutants [8], which can be used for biogas generation via AD. Success has been reported for the generation of biomethane from brewery wastewater and slurry, likewise, the reduction of the organic pollutant of dairy, sugar and yeast wastewater via AD have also been reported [9]-[11].

The use of industrial wastewater for provision of micronutrients such as iron (Fe), manganese ( $\mathrm{Mn}$ ) etc. for digestion is gaining grounds, the use of slaughterhouse wastewater for digestion processes are on the increase in the last five (5) years [12], [13], but little has been reported on the tremendous effect agricultural processing industrial wastewater for digestion processes to produce biogas. This study is geared towards investigating the effect of brewery, dairy and sugar industrial wastewater on the yield of biogas via AcoD with SS using a BMP test. Therefore, industrial wastewaters with high carbon content and high chemical oxygen demand (a form of acetate) were utilized as co-substrates to enhance biomethane production from sewage sludge and likewise achieving chemical oxygen demand reduction of these industrial wastewater. Lastly, the use of kinetic models in AD processes has shown to describe the connection between substrate 
consumption, biogas generation as well as the microorganism growth rate. The models can be used for prediction, digester functionality control and reactor design optimization [14]. Kinetic models applied to both AD / AcoD are first-order kinetic as seen in equation 1, Monod, Contois, Haldane, Chen and Hashimoto, modified Gompertz as seen in equation 2, and dual pooled first-order kinetic model [4], [15], [16]. Such models assist in simulating the process of AcoD and can be modified to include inhibition parameters.

$$
\begin{aligned}
& M(t)=M m\left(1-e^{-K_{H} t}\right) \\
& M(t)=M o \times \exp \left\{-\exp \left[\frac{R \max \times e}{M o}(\lambda-t)+1\right]\right\}
\end{aligned}
$$

\section{MATERIAL AND METHODS}

\section{A. Inoculum and substrate sampling}

Anaerobic digested sludge was used as the inoculum which was collected from a Municipal wastewater treatment plant in KwaZulu-Natal (SA) with digester capacity of about $2000 \mathrm{~m}^{3}$. The inoculum was used to ensure quick acclimatization of the anaerobic microbial consortium. The substrates used were SS, brewery wastewater (BW), dairy wastewater (DW) and sugar wastewater (SW). These wastewaters were collected from the effluent section of the different individual plants while the SS used was collected from the primary settling tank after gravitational settling. All samples were immediately kept in a cold room at $4^{\circ} \mathrm{C}$ and characterization analysis were carried out within 48 hours.

\section{B. Analytical methods}

In accordance with standard methods [17], the following analysis was carried out for each substrate: $\mathrm{pH}$, total solids (TS), total suspended solids (TSS), volatile solids and suspended solid (VS and VSS) and chemical oxygen demand (COD) while for the inoculum, the solids (TS, VS) were the only parameters analyzed. All characterization analysis was carried out in duplicate.

TS and VS were measured gravimetrically after drying at $105^{\circ} \mathrm{C}$ for 24 hours and ignition at $550^{\circ} \mathrm{C}$ for $30 \mathrm{mins}$, respectively. TSS and VSS were also determined gravimetrically after filtering the solution through $1.2 \mu \mathrm{m}$ Munktell Ahlstrom glass filter, then dried at $105^{\circ} \mathrm{C}$ for $1 \mathrm{~h}$ and combustion at $550^{\circ} \mathrm{C}$ for 30 mins, respectively. COD was determined using the closed reflux method standard 5530D. A $2.5 \mathrm{~mL}$ aliquot of each wastewater was poured into COD vials which contain digestion solution and later digested for $2 \mathrm{~h}$ at $150^{\circ} \mathrm{C}$ using $\mathrm{HACH}$ COD block heater before being analyzed using HACH DR3900 spectrophotometer. The COD high range (HR) stored program for $0-1500 \mathrm{mg} / \mathrm{L}$ range was utilized for the measurement of COD concentration. It should be noted that the wastewaters aliquot used for COD measurement contained wastewater to distil water in the ratio, 1:4 respectively as this was carried out to get a measurement within the COD range on the stored program.

\section{Experimental setup}

The BMP study was carried out to determine the co-digestion efficiency of each wastewater with the SS. Each experiment was carried out in a $1000 \mathrm{~mL}$ Duran Schott bottles which were used as bioreactors with a working volume of $900 \mathrm{~mL}$ at two working temperatures of $25^{\circ} \mathrm{C}$ and $35^{\circ} \mathrm{C}$. The bioreactors were filled to $80 \%$ of their capacity and the remaining $20 \%$ used as the headspace. The bioreactors were closed with a three-port screw cap and were sealed with a silicone seal to prevent any gas leakage. To maintain the temperatures, each set of the experiment were kept in a water bath and were manually shaken once daily.

The volume ratio for each bioreactor was $2: 1: 1$ for inoculum, $\mathrm{SS}$, and wastewater, respectively. The inoculum-substrate ratio (ISR) of each mixture were approximately $1 \mathrm{~g} \mathrm{VSi} / \mathrm{gVSs}$. The control test was the mixture of inoculum and SS since the effect of the industrial wastewater on biomethane yield was to be measured.

Another factor considered in this study is the varying of the inoculum to substrates ratio (ISR). Three ISRs was considered in this study which are: $1: 2,1: 1$ and 2:1. The calculations for the ISR were based on the VS content of the inoculum and the substrates. The value of the VS for the inoculum, sludge and the wastewater used are shown in Table I.

Downward water displacement method was used to determine the volume of gas produced daily. The amount of methane produced was calculated by subtracting the volume produced by the control from each mixture.

The optimum run from the ISR in terms of biogas production was used for the kinetic model analysis. An equal volume of substrate and the corresponding volume of inoculum for ISR of $1: 2$. The experiment was run for 24 hours at $25^{\circ} \mathrm{C}$ and was made to run continuously by mixing using magnetic stirrer for the duration of the experiment.

\section{Statistical analysis}

All tests were carried out in duplicate and cumulative data were analyzed using the solver add-on of Excel by Microsoft ${ }$. For the curve fitting of the kinetics models that were analyzed, the sum of squares error method was utilized to calculate the deviation between the measured and the predicted value by the models [18]. The sum of squares error was set as the objective function; it was then minimized using Solver add-in while changing the other parameters.

TABLE I: VOLUME OF INOCULUM AND SUBSTRATE FOR ISR SETUP

\begin{tabular}{lllll}
\hline \hline Inoculum & \multicolumn{3}{c}{ Substrate } & ISR \\
\hline Value $(\mathrm{mg})$ & Volume $(\mathrm{mL})$ & Value $(\mathrm{mg})$ & Volume $(\mathrm{mL})$ & \\
\hline 2232 & 300 & 4464 & 482 & $1: 2$ \\
\hline 4464 & 400 & 4464 & 321 & $1: 1$ \\
\hline 4464 & 546 & 2232 & 220 & $2: 1$ \\
\hline \hline
\end{tabular}


temperature of the BMP process under study is the same as the digester from the sampling site. The result shows that the yield of biogas from DW mix operated at $25^{\circ} \mathrm{C}$ was more than other

TABLE II: CHARACTERISTICS OF INOCULUM AND SUBSTRATES

\begin{tabular}{llllll}
\hline \hline Parameters & Inoculum & $\begin{array}{l}\text { Sewage } \\
\text { sludge }\end{array}$ & SW & BW & DW \\
\hline $\mathrm{pH}$ & 7.19 & 5.72 & 6.30 & 5.00 & 9.13 \\
\hline $\mathrm{TS}(\mathrm{mg} / \mathrm{L})$ & 12100 & 42210 & 4515 & 7779 & 4603 \\
\hline $\mathrm{VS}(\mathrm{mg} / \mathrm{L})$ & 6460 & 30980 & 3414 & 5050 & 3976 \\
\hline $\mathrm{COD}(\mathrm{mg} / \mathrm{L})$ & & & 7130 & 6463 & 3013 \\
\hline \hline
\end{tabular}

\section{RESULTS AND DISCUSSION}

\section{A. Characterization}

The characterization result for each substrate and the inoculum used are shown in Table II. The results indicated that the wastewater streams have high organic content which is highly biodegradable base on the VS/TS ratios, making them suitable for the AD process. The result for brewery wastewater was in correlation to the range as stated by [19], likewise, the range stated by [11], [20], [21] for sugar and dairy wastewater respectively were inconsonant with the results obtained.

\section{B. Effect of temperature on biomethane production}

To consider the effect of temperature on the co-digestion process, the BMP test investigated two temperatures. This was done as the temperature is one of the factors reported to have a tremendous effect on the yield of biogas and degradability of substrates during the AD process [22], [23]. As shown in Figure 1 , it was observed that the BMP assays operated at $35^{\circ} \mathrm{C}$ generally had a higher biogas yield than the same assay operated at $25^{\circ} \mathrm{C}$ apart from the DWmix which had a higher yield at $25^{\circ} \mathrm{C}$ than the corresponding assay at $35^{\circ} \mathrm{C}$.

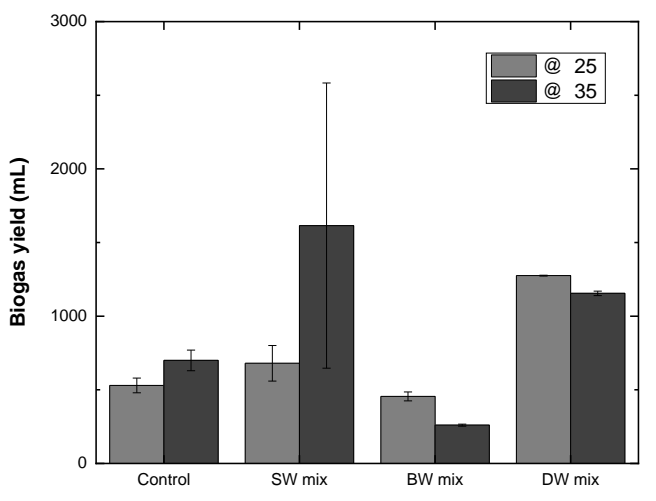

Fig. 1: Comparison of overall biogas yield for each BMP assay at both temperatures.

It should be noted that the digester from which the inoculum was obtained was operated at $25^{\circ} \mathrm{C}$. Studies have also reported that a good yield of biomethane is achieved when the assays at both temperatures knowing that the inoculum was taken from a digester operated at $25^{\circ} \mathrm{C}$, on the other hand, the yield from $\mathrm{SW}$ mix at $35^{\circ} \mathrm{C}$ was higher than DW mix at $25^{\circ} \mathrm{C}$. Normalized biogas yield based on the equation 3 [24]. The total volume of biomethane produced by the control was subtracted from the total volume of the other mixtures to evaluate production yield by each substrate. The resulting volume was then normalized against the initial VS of each wastewater introduced to each reactor to give the biomethane yield per $\mathrm{g}$ VS of each wastewater.

$A\left(m L \frac{\text { biomethane }}{g V S_{s}}\right)=\frac{B(m L)}{\frac{g V S_{s}}{m L} \times C(m L)}$

$\mathrm{A}=$ Normalized biomethane production

$\mathrm{B}=\mathrm{mL}$ of gas produced by the substrate only

$\mathrm{C}=\mathrm{mL}$ of substrate added to the reactor.

It is observed that $\mathrm{SW}$ mix produced 219.70 and 1354.83 $\mathrm{NmL}$ biogas $\mathrm{gVS}^{-1}$ at $25^{\circ} \mathrm{C}$ and $35^{\circ} \mathrm{C}$ respectively while that of DW mix was 936.80 and $584.71 \mathrm{NmL}$ biogas $\mathrm{gVS}^{-1}$. The result for BW mix was not included because the normalized yield tends to negative.

\section{Effect of wastewater}

The addition of wastewater help reduces the lag phase duration which is usually encountered when using agricultural biomass as co-substrates for SS [25]. Figure 1 shows the volume of biogas for the BMP assay at both temperature, which indicates that the BMP assay with wastewater produced more biogas by $134 \%$ and $67 \%$ for SWmix and DWmix respectively than that of the control except for the BWmix. The result shows a steady increase in the production of biomethane with the assay with wastewater as compared to the control which had a maximum increase within the first 5 days and declined production rate after this day (See supplementary figure). The low biomethane production for BWmix could be due to volatile fatty acids inhibition which accumulates on the surface of the mixture because the previous study has reported favorably high yield for digestion of BW [26].

\section{Effect of Inoculum-substrate ratio (ISR)}

The result for the ISR experiment reveals improve overall biomethane production as seen in Figure 2. The overall result indicated that both wastewaters performed best at $25^{\circ} \mathrm{C}$ as opposed to the result obtained during the preliminary runs though SWmix had a maximum biomethane production at $35^{\circ} \mathrm{C}$ for ISR 1:1. SW mix with ISR of 1:2 had the highest production of $1088.7 \mathrm{~mL}$ biogas while the highest biomethane production was SWmix with ISR of $1: 1$ being $67 \%$ of the biogas production and DWmix with ISR of 2:1 had the second highest overall $(968 \mathrm{~mL})$ and biomethane production of $55 \%$. Generally, the SW mix assay performed better as compared to the DWmix as seen in Figure 2. The progression from highest to lowest is $\mathrm{S} 12_{25}>\mathrm{D} 21_{25}>\mathrm{S} 11_{25}>\mathrm{S} 11_{35}>\mathrm{D} 12_{35}>\mathrm{S} 12_{35}>\mathrm{S} 21_{35}>\mathrm{S} 21_{25}>\mathrm{D} 21_{35}$ 
$>\mathrm{D} 12_{25}>\mathrm{D} 11_{25}$ with production rate of $40.32,35.88,34.48$, $30.05,28.86,26.33,21.18,14.09,12.52,2.96$ and $1.22 \mathrm{~mL} /$ day, respectively.

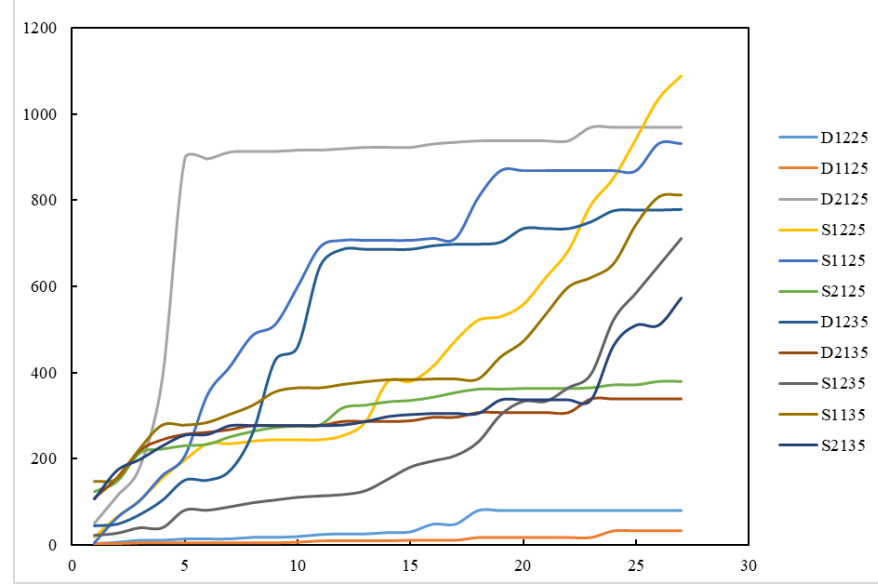

Fig. 2: Cumulative biomethane production for varying ISR assay

The result obtained was in agreement with [27], [28], whose study indicated that SIR of 1.5 and 2 which is commensurate to ISR of 0.75 and 0.5 had the highest methane generation when they worked with piggery slaughterhouse wastes and rape straw co-digested with dairy manure respectively. Though this was in contrast with [29]whose work on fat, oil and grease revealed less than $60 \%$ methane production at SIR of $2-4$.

\section{E. Kinetics Analysis}

The results validate the assertion of [4] whose review state that first order and Gompertz model have been used to simulate the production of methane for co-digestion system. In this study, the first-order kinetic model was the best fit for the SW experiment with an $\mathrm{R}^{2}$ value of 0.996 while Gompertz model had an $R^{2}$ value of 0.988 as seen in Figure 3 and 4 . The model terms for each model are shown in Table 3.

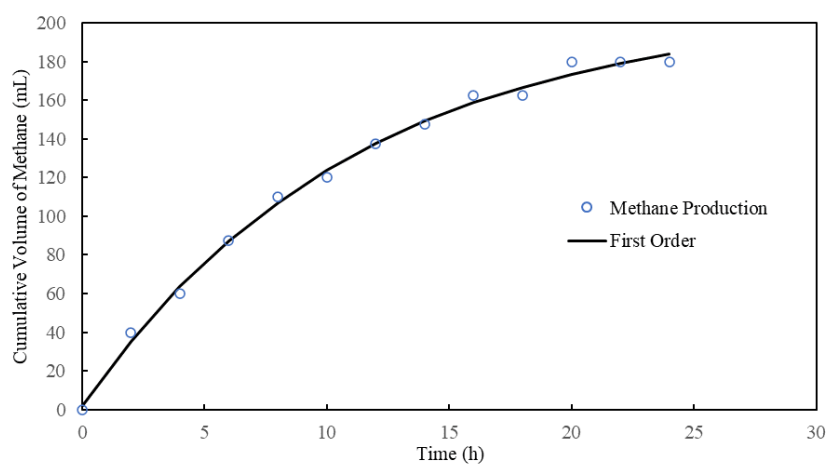

Fig. 3: Kinetics Models Fitting for First Order Kinetic Model

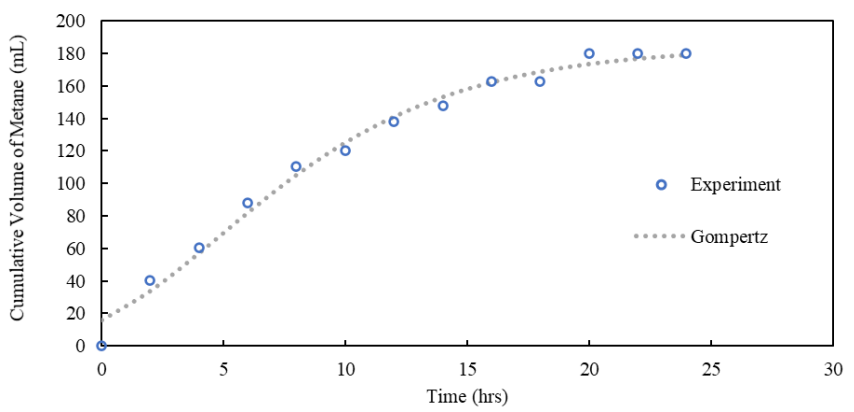

Fig. 4: Kinetics Models Fitting for simplified Gompertz Model

TABLE III: Model TeRmS FOR CUMUlative Methane PROdUCtion

\begin{tabular}{cccc}
\hline \hline \multicolumn{2}{c}{ First Order } & \multicolumn{2}{c}{ Simplified Gompertz } \\
\hline Parameter & Value & Parameter & Value \\
\hline Mm & 207 & $\mathrm{Mm}$ & 184 \\
\hline $\mathrm{k}$ & 0.092 & $\mathrm{k}$ & 4.843 \\
\hline $\mathrm{SSE}$ & 155.22 & $\mathrm{c}$ & 0.184 \\
\hline & & $\mathrm{SSE}$ & 516.56 \\
\hline
\end{tabular}

\section{CONCLUSION}

The use of agro-industrial wastewater proves to be a promising co-substrate for SS to improve biogas yield as shown for SW and DW with a yield of 1354.83 and $936.8 \mathrm{NmLgVS}^{-1}$ respectively. The results of the characterization and the yield of biomethane based on the effect of temperature was inconsonant with previous studies. Likewise, varying the ISR could help improve the methane content of the produced biogas. The first order kinetic model was found to be the best model for predicting BMP for SW among the two kinetic models used $\left(R^{2}=0.996\right)$.

\section{ACKNOWLEDGMENT}

This study was funded by the National Research Foundation (NRF) in collaboration with Durban University of Technology (DUT), Durban.

\section{REFERENCES}

[1] S. Achinas, V. Achinas, and G. J. W. Euverink, "A Technological Overview of Biogas Production from Biowaste," Engineering, 2017, doi: 10.1016/J.ENG.2017.03.002.

[2] K. Hagos, J. Zong, D. Li, C. Liu, and X. Lu, "Anaerobic co-digestion process for biogas production: Progress, challenges and perspectives," Renewable and Sustainable Energy Reviews. 2017, doi: 10.1016/j.rser.2016.11.184.

[3] J. Mata-Alvarez, J. Dosta, M. S. Romero-Güiza, X. Fonoll, M. Peces, and S. Astals, "A critical review on anaerobic co-digestion achievements between 2010 and 2013," Renewable and Sustainable Energy Reviews. 2014, doi: 10.1016/j.rser.2014.04.039.

[4] S. Xie et al., "Anaerobic co-digestion: A critical review of mathematical modelling for performance optimization," Bioresource Technology. 2016, doi: 10.1016/j.biortech.2016.10.015.

[5] M. Von Sperling, "Wastewater Characteristics, Treatment and Disposal," Water Intell. Online, 2015, doi: 10.2166/9781780402086.

[6] D. Wang, J. Zhao, G. Zeng, Y. Chen, P. L. Bond, and X. Li, "How Does Poly(hydroxyalkanoate) Affect Methane Production from the Anaerobic Digestion of Waste-Activated Sludge?," Environ. Sci. Technol., 2015, 
doi: 10.1021/acs.est.5b03112.

[7] F. Alatriste-Mondragón, P. Samar, H. H. J. Cox, B. K. Ahring, and R. Iranpour, "Anaerobic codigestion of municipal, farm, and industrial organic wastes: a survey of recent literature," Water Environ. Res., vol. 78, no. 6, pp. 607-636, 2006.

[8] M. Tariq, M. Ali, and Z. Shah, "Characteristics of industrial effluents and their possible impacts on quality of underground water," Soil Env., 2006.

[9] H. Chen, S. Chang, Q. Guo, Y. Hong, and P. Wu, "Brewery wastewater treatment using an anaerobic membrane bioreactor," Biochem. Eng. J., 2016, doi: 10.1016/j.bej.2015.10.006.

[10] M. Evren, H. Ozgun, R. Kaan, and I. Ozturk, "Anaerobic Treatment of Industrial Effluents: An Overview of Applications," in Waste Water Treatment and Reutilization, 2011.

[11] D. Karadag, O. E. Körołlu, B. Ozkaya, and M. Cakmakci, "A review on anaerobic biofilm reactors for the treatment of dairy industry wastewater," Process Biochemistry. 2015, doi: 10.1016/j.procbio.2014.11.005.

[12] D. Hidalgo, J. M. Martín-Marroquín, and F. Corona, "The effect of feed composition on anaerobic co-digestion of animal-processing by-products," J. Environ. Manage., 2018, doi: 10.1016/j.jenvman.2017.06.033

[13] L. Zhang, Y. W. Lee, and D. Jahng, "Anaerobic co-digestion of food waste and piggery wastewater: Focusing on the role of trace elements," Bioresour. Technol., 2011, doi: 10.1016/j.biortech.2011.01.082.

[14] J. M. Ondari, "ANAEROBIC CO-DIGESTION OF ABATTOIR AND TEXTILE INDUSTRY WASTEWATER IN A UASB REACTOR," 2015.

[15] C. Dennehy et al., "Synergism and effect of high initial volatile fatty acid concentrations during food waste and pig manure anaerobic co-digestion," Waste Manag., 2016, doi: 10.1016/j.wasman.2016.06.032.

[16] G. K. Kafle and L. Chen, "Comparison on batch anaerobic digestion of five different livestock manures and prediction of biochemical methane potential (BMP) using different statistical models," Waste Manag., 2016, doi: 10.1016/j.wasman.2015.10.021.

[17] APHA, AWWA, and WEF, Standard Methods for the Examination of Water and Wastewater, centinial addition. 2005.

[18] A. Bechmann and S. Lomborg, "Model Diagnostics for Regression," New Media Soc., 2013.

[19] A. M. Enitan, J. Adeyemo, S. Kumari, F. M. Swalaha, and F. Bux, "Characterization of Brewery Wastewater Composition," Int. J. Environ. Ecol. Eng., 2015.

[20] J. Fito, N. Tefera, and S. W. H. Van Hulle, "Sugarcane biorefineries wastewater: bioremediation technologies for environmental sustainability," Chemical and Biological Technologies in Agriculture. 2019, doi: 10.1186/s40538-019-0144-5.

[21] J. P. Kushwaha, "A review on sugar industry wastewater: sources, treatment technologies, and reuse," Desalin. Water Treat., 2015, doi: 10.1080/19443994.2013.838526.

[22] E. K. Armah, M. Chetty, and N. Deenadayalu, "Biomethane potential of agricultural biomass with industrial wastewater for biogas production," Chem. Eng. Trans., 2019, doi: 10.3303/CET1976236.

[23] G. Güngör-Demirci and G. N. Demirer, "Effect of initial COD concentration, nutrient addition, temperature and microbial acclimation on anaerobic treatability of broiler and cattle manure," Bioresour. Technol., 2004, doi: 10.1016/j.biortech.2003.10.019.

[24] L. Moody and P. E. L. Moody, "Using Biochemical Methane Potentials Using Biochemical Methane Potentials \& Anaerobic Toxicity Assays \& Anaerobic Toxicity Assays."

[25] D. Hidalgo, J. M. Martín-Marroquín, and F. Corona, "The effect of feed composition on anaerobic co-digestion of animal-processing by-products," J. Environ. Manage., 2018, doi: 10.1016/j.jenvman.2017.06.033.

[26] M. K. Arantes, H. J. Alves, R. Sequinel, and E. A. da Silva, "Treatment of brewery wastewater and its use for biological production of methane and hydrogen," International Journal of Hydrogen Energy. 2017, doi: 10.1016/j.ijhydene.2017.08.206.

[27] Y. M. Yoon, S. H. Kim, K. S. Shin, and C. H. Kim, "Effects of substrate to inoculum ratio on the biochemical methane potential of piggery slaughterhouse wastes," Asian-Australasian J. Anim. Sci., 2014, doi: 10.5713/ajas.2013.13537.

[28] X. Ma, T. Jiang, J. Chang, Q. Tang, T. Luo, and Z. Cui, "Effect of
Substrate to Inoculum Ratio on Biogas Production and Microbial Community During Hemi-Solid-State Batch Anaerobic Co-digestion of Rape Straw and Dairy Manure," Applied Biochemistry and Biotechnology. 2019, doi: 10.1007/s12010-019-03035-9.

[29] R. Nazaitulshila, A. Idris, R. Harun, and W. A. K. G. Wan Azlina, "The influence of inoculum to substrate ratio on the biochemical methane potential of fat, oil, and grease in batch anaerobic assays," Energy Sources, Part A Recover. Util. Environ. Eff., 2015, doi: 10.1080/15567036.2014.907374.

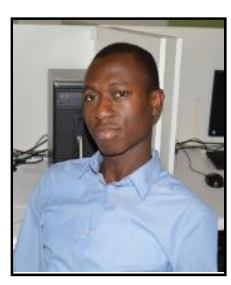

Jeremiah A. Adedeji, Student Member of Nigerian Society of Engineers. He received the Bachelor of Technology with Honors, BTech (Hons) and from the Ladoke Akintola University of Technology, Nigeria in 2011. He is currently working towards his Meng (Master of Engineering) in Chemical Engineering at Durban University of Technology, South Africa. 